\title{
Structural and Kinetic Characteristics of 1,4-Dioxane-Degrading Bacterial Consortia Containing the Phylum TM7
}

\author{
Ji-Hyun Nam ${ }^{1}$, Jey-R S. Ventura ${ }^{2}$, Ick Tae Yeom ${ }^{3}$, Yongwoo Lee ${ }^{4}$, and Deokjin Jahng ${ }^{1 *}$ \\ ${ }^{1}$ Department of Environmental Engineering and Energy, Myongji University, Yongin 17058, Republic of Korea \\ ${ }^{2}$ Department of Engineering Science, College of Engineering and Agro-Industrial Technology, University of the Philippines, Los Baños, \\ College, 4031 Laguna, Philippines \\ ${ }^{3}$ Department of Civil and Environmental Engineering, Sungkyunkwan University, Suwon 16419, Republic of Korea \\ ${ }^{4}$ Department of Chemistry and Applied Chemistry, College of Science and Technology, Hanyang University, Ansan 15588, Republic of Korea
}

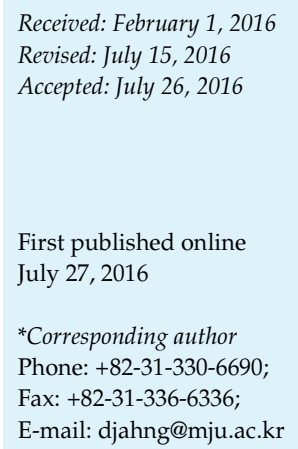

First published online July 27, 2016

${ }^{*}$ Corresponding author Phone: +82-31-330-6690; Fax: +82-31-336-6336; E-mail: djahng@mju.ac.kr

pISSN 1017-7825, eISSN 1738-8872

Copyright@ 2016 by

The Korean Society for Microbiology and Biotechnology
1,4-Dioxane-degrading bacterial consortia were enriched from forest soil (FS) and activated sludge (AS) using a defined medium containing 1,4-dioxane as the sole carbon source. These two enrichments cultures appeared to have inducible tetrahydrofuran/dioxane and propane degradation enzymes. According to qPCR results on the 16S rRNA and soluble di-iron monooxygenase genes, the relative abundances of 1,4-dioxane-degrading bacteria to total bacteria in FS and AS were $29.4 \%$ and $57.8 \%$, respectively. For FS, the cell growth yields (Y), maximum specific degradation rate $\left(\mathrm{V}_{\max }\right)$, and half-saturation concentration $\left(\mathrm{K}_{\mathrm{m}}\right)$ were $0.58 \mathrm{mg}$-protein/mg-dioxane, $0.037 \mathrm{mg}$-dioxane $/ \mathrm{mg}$-protein $\cdot \mathrm{h}$, and $93.9 \mathrm{mg} / \mathrm{l}$, respectively. For AS, $\mathrm{Y}, \mathrm{V}_{\max }$, and $\mathrm{K}_{\mathrm{m}}$ were $0.34 \mathrm{mg}$-protein/mg-dioxane, $0.078 \mathrm{mg}$-dioxane/mg-protein $\cdot \mathrm{h}$, and $181.3 \mathrm{mg} / \mathrm{l}$, respectively. These kinetics data of FS and AS were similar to previously reported values. Based on bacterial community analysis on 16S rRNA gene sequences of the two enrichment cultures, the FS consortium was identified to contain 38.3\% of Mycobacterium and $10.6 \%$ of Afipia, similar to previously reported literature. Meanwhile, $49.5 \%$ of the AS consortium belonged to the candidate division TM7, which has never been reported to be involved in 1,4-dioxane biodegradation. However, recent studies suggested that TM7 bacteria were associated with degradation of non-biodegradable and hazardous materials. Therefore, our results showed that previously unknown 1,4-dioxane-degrading bacteria might play an important role in enriched AS. Although the metabolic capability and ecophysiological significance of the predominant TM7 bacteria in AS enrichment culture remain unclear, our data reveal hidden characteristics of the TM7 phylum and provide a perspective for studying this previously uncultured phylotype.

Keywords: 1,4-Dioxane-degrading bacterial consortia, candidate division TM7, Mycobacterium, Afipia, kinetic parameters, soluble di-iron monooxygenase

\section{Introduction}

1,4-Dioxane is a colorless and flammable liquid with a faintly sweet odor. It has been widely used as a stabilizer for chlorinated solvents such as 1,1,1-trichloroethane, trichloroethene (TCE), and tetrachloroethene [31, 32, 40, 50]. 1,4-Dioxane is also used as a solvent in the manufacturing processes of ethylene glycol and ethylene oxide [38].
Owing to its extensive use, 1,4-dioxane has frequently been detected as a persistent contaminant in surface water and groundwater [19, 40,50]. 1,4-Dioxane is recognized as a serious pollutant in aquatic environments because of its acute and chronic toxicity as well as its suspected carcinogenicity [4, 42]. The United States Environmental Protection Agency classifies 1,4-dioxane as one of the Class 2B carcinogens with a high possibility of causing human 
cancer $[19,50]$. The International Agency for Research on Cancer also categorizes 1,4-dioxane as Group 2B (possibly carcinogenic to humans) [19]. Consequently, the World Health Organization has established the guidelines for 1,4dioxane in drinking water at $50 \mu \mathrm{g} / 1$ since 2006. In Korea, the Ministry of Environment (MOE) has set the quality limit of 1,4-dioxane in drinking water at $50 \mu \mathrm{g} / 1$ since 2012. Furthermore, the MOE has regulated the concentration of 1,4-dioxane in industrial wastewater effluents at below 4 $\mathrm{mg} / 1$ since 2013 .

Since 1,4-dioxane has a high miscibility with water, low Henry's constant $\left(5 \times 10^{-6} \mathrm{~atm} \mathrm{m^{3 }} / \mathrm{mol}\right.$ at $\left.20^{\circ} \mathrm{C}\right)$, and high hydrophilic nature $\left(\log \mathrm{K}_{\mathrm{ow}}=-0.27\right)[27,31,33,50]$, it can persist for a long time, especially in aquatic environments [40]. Among traditional physicochemical technologies, advanced oxidation processes (AOPs) using ozone, hydrogen peroxide, UV light, and their combinations have been found to be effective in removing 1,4-dioxane [41]. However, AOPs require high energy consumption and operational costs.

On the other hand, microbial degradation of 1,4-dioxane is considered as a cost-effective and efficient treatment technology $[3,15,39,51]$. Therefore, several attempts have been made to isolate and characterize 1,4-dioxane-degrading bacteria. To date, dioxane metabolism has been reported in 12 gram-positive bacterial strains, including Pseudonocardia dioxanivorans CB1190 [30, 37], P. benzenivorans B5 [31], Pseudonorcardia tetrahydrofuranoxydans K1 [18], Pseudonorcardia sp. ENV478 [45], P. sp. D17 [41], Mycobacterium vaccae JOB5 [3], Mycobacterium sp. PH-06 [19], Mycobacterium sp. D6 [41], Mycobacterium sp. D11 [41], Rhodococcus ruber 219 [3], Rhodococcus sp. ENV425 [45], and Rhodococcus sp. RR1 [31]. The biodegradative pathways of 1,4-dioxane have also been reported in a gram-negative bacterium, Afipia sp. D1 [41], and in the fungus Cordyceps sinensis [35]. In particular, 8 bacterial strains (P. dioxanivorans CB1190, P. benzenivorans B5, Pseudonorcardia sp. D17, Mycobacterium PH-06, Mycobacterium sp. D6, Mycobacterium sp. D11, R. ruber 219, and Afipia sp. D1) and a fungal strain (C. sinensis) have been found to be capable of growing on 1,4-dioxane as the sole carbon and energy source. However, the growth and removal rates of these microorganisms by 1,4-dioxane are known to be very low $[50,51]$ because the biological processes in these strains require a long hydraulic retention time.

Most of the 1,4-dioxane-degrading microorganisms are unable to use 1,4-dioxane as the sole carbon source because these strains are unable to induce necessary genes and/or to mineralize 1,4-dioxane completely [45]. For growth and gene induction support, these strains require primary growth substrates such as tetrahydrofuran (THF) $[3,21,48$, 50], propane [3, 31], toluene [3, 21, 31], methane [31], and ethanol [21]. It was also shown that co-metabolic dioxane transformation was enhanced by the growth-inducing substrate THF [45, 50]. However, many other studies showed that THF inhibited the dioxane transformation of pure and mixed microbial cultures growing on THF as the primary substrate [31, 40,48]. Therefore, although it was not impossible, dioxane degradation remained very limited for these strains.

In the present study, bacterial enrichment cultures with a high capability in degrading 1,4-dioxane as the sole carbon and energy source were obtained from forest soil (FS) and activated sludge (AS), and the bacterial composition and kinetic parameters of 1,4-dioxane biodegradation were analyzed. In addition, the genus Mycobacterium and candidate division TM7 capable of growing on 1,4-dioxane were reported in this study.

\section{Materials and Methods}

\section{Enrichment Culture of 1,4-Dioxane-Degrading Bacterial Consortia}

For enrichment, $10 \mathrm{~g}$ of FS collected from a forest near the Yongin Campus of Myongji University and of AS obtained from a domestic wastewater treatment plant in Yongin, Korea were washed three times with $200 \mathrm{ml}$ of ammonium mineral salts (AMS) [37] medium. Then pre-washed FS was added into a $500 \mathrm{ml}$ Erlenmeyer flask containing $200 \mathrm{ml}$ of AMS medium so that the concentration of total suspended solids (TSS) was 1,200 mg/l. This flask was incubated aerobically at $30^{\circ} \mathrm{C}$ on a shaker rotating at $120 \mathrm{rpm}$. The pre-washed AS was cultured in a $5 \mathrm{~L}$ cylindrical reactor (ID $170 \mathrm{~mm} \times \mathrm{H} 260 \mathrm{~mm}$ ) containing $2 \mathrm{~L}$ of AMS medium and $1,200 \mathrm{mg} / 1$ of TSS. The reactor was stirred at $200 \mathrm{rpm}$ and was supplied with air at $0.2 \mathrm{l} / \mathrm{min}$ using a flowmeter (Dwyer Instruments, USA). The reactor was kept at room temperature $\left(22-25^{\circ} \mathrm{C}\right)$. For both enrichment cultures, AMS medium was supplemented with about $200-250 \mathrm{mg} / 1$ of 1,4-dioxane as the sole carbon and energy source. After about 3 weeks of enrichment culture (5-6 successive transfers), the concentration of 1,4-dioxane was lowered to about $100 \mathrm{mg} / \mathrm{l}$. Subsequently, enrichment cultivation was continued for 300 days by transferring TSS into fresh AMS every week in early stages and every 2-3 days in later stages. TSS of the previous culture was centrifuged and washed three times with phosphate-buffered saline $(\mathrm{pH}$ 7.4) before transfer to remove mineral salt precipitates.

\section{Gene Library Construction and Phylogenetic Analysis}

The genomic DNA of the enriched culture was extracted using the FastDNA SPIN kit for soil (MP Biomedicals, USA) according to the manufacturer's instructions. For the extracted genomic DNA, the 16S rRNA and soluble di-iron monooxygenase (SDIMO) 
Table 1. Primer sets for the $16 \mathrm{~S}$ rRNA and SDIMO genes used in this study.

\begin{tabular}{|c|c|c|c|c|c|c|}
\hline Target gene & Primer & Sequence $\left(5^{\prime} \rightarrow 3^{\prime}\right)$ & $\begin{array}{l}\text { Amplicon } \\
\text { size (bp) }\end{array}$ & $\begin{array}{l}\text { Annealing } \\
\text { temp. }\left({ }^{\circ} \mathrm{C}\right)\end{array}$ & Method & Reference \\
\hline \multirow{4}{*}{$\begin{array}{l}\text { Eubacterial } \\
16 \mathrm{~S} \text { rRNA } \\
\text { gene }\end{array}$} & $27 \mathrm{~F}$ & AGAGTTTGATCMTGGCTCAG & \multirow[t]{2}{*}{1,503} & \multirow[t]{2}{*}{50} & \multirow{2}{*}{$\begin{array}{l}\text { Gene library and } \\
\text { standard for } \mathrm{qPCR}^{\mathrm{a}}\end{array}$} & \multirow[t]{2}{*}{ [23] } \\
\hline & $1492 \mathrm{R}$ & GGYTACCTTGTTACGACTT & & & & \\
\hline & $357 \mathrm{~F}$ & CTACGGGAGGCAGCAG & \multirow[t]{2}{*}{194} & \multirow[t]{2}{*}{55} & \multirow[t]{2}{*}{ qPCR } & \multirow[t]{2}{*}{ [34] } \\
\hline & $517 \mathrm{R}$ & ATTACCGCGGCTGCTGG & & & & \\
\hline \multirow{4}{*}{$\begin{array}{l}\text { SDIMO } \\
\text { gene }\end{array}$} & NVC65 & CARATGYTNGAYGARGTNCGNCA & \multirow[t]{2}{*}{1,100} & \multirow[t]{2}{*}{55} & \multirow[t]{2}{*}{ Standard for $\mathrm{qPCR}^{\mathrm{b}}$} & \multirow[t]{4}{*}{ [5] } \\
\hline & NVC58 & CGDATRTCRTCDATNGTCCA & & & & \\
\hline & NVC57 & CAGTCNGAYGARKCSCGNCAYAT & \multirow[t]{2}{*}{420} & \multirow[t]{2}{*}{55} & \multirow{2}{*}{$\begin{array}{l}\text { Gene library and } \\
\text { qPCR }\end{array}$} & \\
\hline & NVC66 & CCANCCNGGRTAYTTRTTYTCRAACCA & & & & \\
\hline
\end{tabular}

${ }^{\mathrm{a}}$ A plasmid standard of the $16 \mathrm{~S}$ rRNA gene containing the target region was generated for primer 27F/1492R using DNA extracted from Escherichia coli KCTC 2441 ${ }^{\mathrm{T}}$.

${ }^{\mathrm{b}}$ A plasmid standard of the SDIMO gene containing the target region was generated for primer NVC65/NVC58 using DNA extracted from the enrichment culture FS.

genes were amplified by PCR using the 27F/1492R and NVC57/ NVC66 primer sets, respectively (Table 1). PCRs were carried out using Ex Taq polymerase (Takara Bio, Japan) with the following thermal cycles: initial denaturation at $95^{\circ} \mathrm{C}$ for $3 \mathrm{~min}$; 30 cycles consisting of $95^{\circ} \mathrm{C}$ for $30 \mathrm{sec}, 50-55^{\circ} \mathrm{C}$ for $30 \mathrm{sec}$, and $72^{\circ} \mathrm{C}$ for 1 min; and a final extension at $72^{\circ} \mathrm{C}$ for $10 \mathrm{~min}$. The PCR products were electrophoresed on a $1 \%(\mathrm{w} / \mathrm{v})$ agarose gel and purified with the QIAquick PCR Purification Kit (Qiagen, Germany). PCR products of the 16S rRNA gene were ligated into the T-Blunt PCR Cloning Kit (Solgent, Korea) and cloned into Escherichia coli DH5 $\alpha$ according to the manufacturer's instructions. The nucleotide sequences of the cloned 16S rRNA and SDIMO genes were determined using the ABI 3730XL DNA Analyzer (Applied Biosystems, USA) at Bionics (Korea). The sequences were identified by BLASTN and the Classifier Services of the National Center for Biotechnology Information (http://ncbi.nlm.nih.gov). Chimeric sequences were examined by the Find Chimeras tool of DECIPHER (http://decipher.cee.wisc.edu/FindChimeras.html). The 16S rRNA and SDIMO gene sequences of the enrichment and reference strains were aligned with the CLUSTALW program [44]. Phylogenetic trees were constructed using the MEGA6 program [43]. An evolutionary distance matrix was generated according to the Kimura 2-parameter model [20], and a phylogenetic tree was inferred using the neighbor-joining method [36]. The neighborjoining tree topology was evaluated by the bootstrap analysis with 1,000 replications [9].

\section{Quantitative Real-Time PCR}

For determining the abundance of total bacteria (16S rRNA gene) and 1,4-dioxane-degrading bacteria (SDIMO gene), $16 \mathrm{~S}$ rRNA and SDIMO genes were amplified by quantitative PCR (qPCR) using the 357F/517R and NVC57/NVC66 primer sets, respectively (Table 1 ). The standards for quantifying the $16 \mathrm{~S}$ rRNA and SDIMO gene copies were prepared with purified plasmid DNA containing the target region of E. coli KCTC $2441^{\mathrm{T}}$ and FS enrichment culture, respectively. The PCR mixture contained $10 \mu \mathrm{l}$ of iQ SYBR Green SuperMix (Bio-Rad, USA), $10 \mathrm{ng}$ of salmon sperm DNA as an internal amplification control (SigmaAldrich, USA), $0.3 \mu \mathrm{M}$ of each primer, $2 \mu \mathrm{l}$ of DNA template, and DNA-free water, yielding a total volume of $20 \mu \mathrm{l}$. qPCR was carried out with the Rotor-Gene Q (Qiagen) using the following cycling parameters: initial denaturing at $95^{\circ} \mathrm{C}$ for $15 \mathrm{~min}$, followed by 45 cycles of $95^{\circ} \mathrm{C}$ denaturation for $15 \mathrm{sec}, 55^{\circ} \mathrm{C}$ of annealing for $20 \mathrm{sec}$, and $72^{\circ} \mathrm{C}$ of extension for $25 \mathrm{sec}$. The fluorescence signal was measured at $55^{\circ} \mathrm{C}$ during each cycle. Melting curve analysis was performed to confirm the specificity of the qPCR results. Each test included triplicate reactions per DNA sample and the appropriate sets of standards.

A plasmid standard containing the target region was generated for each primer set using DNA extracted from the appropriate positive control sample (Table 1). The amplified products were run on a $1 \%$ agarose gel to confirm the specificity of the amplification and the identified standard DNA sequence within plasmids. DNA concentrations were determined by the Quant-iT PicoGreen dsDNA Assay Kit (Invitrogen, USA). Standard curves were generated using quintuplicate 10-fold dilutions of plasmid DNA. Target copy numbers for each reaction were calculated from the standard curves by assuming that the average molecular mass of a double-stranded DNA molecule was $660 \mathrm{~g} / \mathrm{mol}$. For all qPCR assays, there was a linear relationship between the log of the plasmid DNA copy number and the calculated threshold cycle value across the specified concentration range $\left(R^{2}>0.98\right.$ in all cases). The copy number of 1,4-dioxane-degrading bacteria in the total bacterial population was estimated by assuming an average of three ribosomal operons per bacterial cell and one SDIMO operon per 1,4-dioxane-degrading bacterial cell [11].

\section{Estimation of Kinetic Parameters}

For kinetics analysis, enriched FS and AS were cultivated in AMS medium containing $100 \mathrm{mg} / \mathrm{l}$ of 1,4-dioxane as the sole carbon and energy source. Cell density was monitored by measuring the optical density at $600 \mathrm{~nm}\left(\mathrm{OD}_{600}\right)$ or by measuring TSS (mg/l) 
filtered with $0.2 \mu \mathrm{m}$ membranes (Advantec, Japan) and dried at $105^{\circ} \mathrm{C}$ for $12 \mathrm{~h}$. 1,4-Dioxane (soluble organic carbon) in the culture medium was measured as non-purgeable organic carbon (NPOC) using a TOC analyzer (TOC-VCPH, Shimadzu, Japan). In comparing the calculated kinetic parameters with previously reported values, the TSS concentration was converted to cellular protein concentration by using the conversion factor of $1 \mathrm{~g}$ TSS = $0.4 \mathrm{~g}$ protein [31]. For the degradation kinetics studies, the Monod (Eq. (1)) and Michaelis-Menten (Eq. (2)) equations were adopted as follows:

$$
\begin{aligned}
& \mu=\mu_{\max } \frac{\mathrm{S}}{\mathrm{K}_{\mathrm{s}}+\mathrm{S}} \\
& \mathrm{v}=\mathrm{V}_{\max } \frac{\mathrm{S}}{\mathrm{K}_{\mathrm{m}}+\mathrm{S}}
\end{aligned}
$$

where $\mu$ is the specific growth rate $\left(h^{-1}\right), \mu_{\max }$ is the maximum specific growth rate $\left(\mathrm{h}^{-1}\right), \mu$ and $\mu_{\max }$ are calculated using $\mathrm{OD}_{600}$ data, $\mathrm{S}$ is the concentration of 1,4-dioxane in $\mathrm{mg} / \mathrm{l}, \mathrm{v}$ is the specific degradation rate for 1,4-dioxane ( $\mathrm{mg} \mathrm{1,4-dioxane/mg} \mathrm{protein} \mathrm{h}$ ), $\mathrm{V}_{\max }$ is the maximum substrate degradation rate (mg 1,4-dioxane/mg protein.h), and $K_{m}$ is the half-saturation constant for 1,4-dioxane in $\mathrm{mg} / \mathrm{l}$. In order to obtain $\mathrm{V}_{\max }, \mu_{\max }$ and $\mathrm{K}_{\mathrm{m}}$, the nonlinear regression method (SigmaPlot, USA) was used. The growth yield (Y) was calculated using Eq. (3):

$$
Y=\frac{X_{2}-X_{1}}{S_{2}-S_{1}}
$$

where $\mathrm{X}$ is the biomass (protein) concentration ( $\mathrm{mg} / \mathrm{l})$, and $\mathrm{S}$ is the concentration ( $\mathrm{mg} / \mathrm{l})$ of the substrate (1,4-dioxane).

\section{Results}

\section{Enrichment Culture and Kinetics}

During the early stages of enrichment, the initial 1,4dioxane concentration in the fresh medium was 100$280 \mathrm{mg} \mathrm{NPOC} / 1$ and the concentration was changed to 100-140 mg NPOC/1 in the later stages. The TSS of the culture was transferred to the fresh medium when concentrations of NPOC decreased below about $40 \mathrm{mg} / \mathrm{l}$. As shown in Fig. 1, the degradation rate of 1,4-dioxane stabilized after 150-180 days. Subsequently, 1,4-dioxane was rapidly consumed in 2-3 days after transfer to fresh medium. In order to determine the kinetic parameters of enriched FS and AS, the concentrations of TSS and 1,4dioxane were measured between Days 270 and 272. As shown in Fig. 2, the concentration of dioxane decreased from 110 to $7.2 \mathrm{mg} \mathrm{NPOC/1}$ (93.5\% removal), while the TSS concentration of FS increased from 400 to $550 \mathrm{mg} / 1$ in $48 \mathrm{~h}$. In the case of enriched AS, the concentration of 1,4-dioxane decreased from 140 to $10.1 \mathrm{mg}$ NPOC/1 (92.8\% removal),
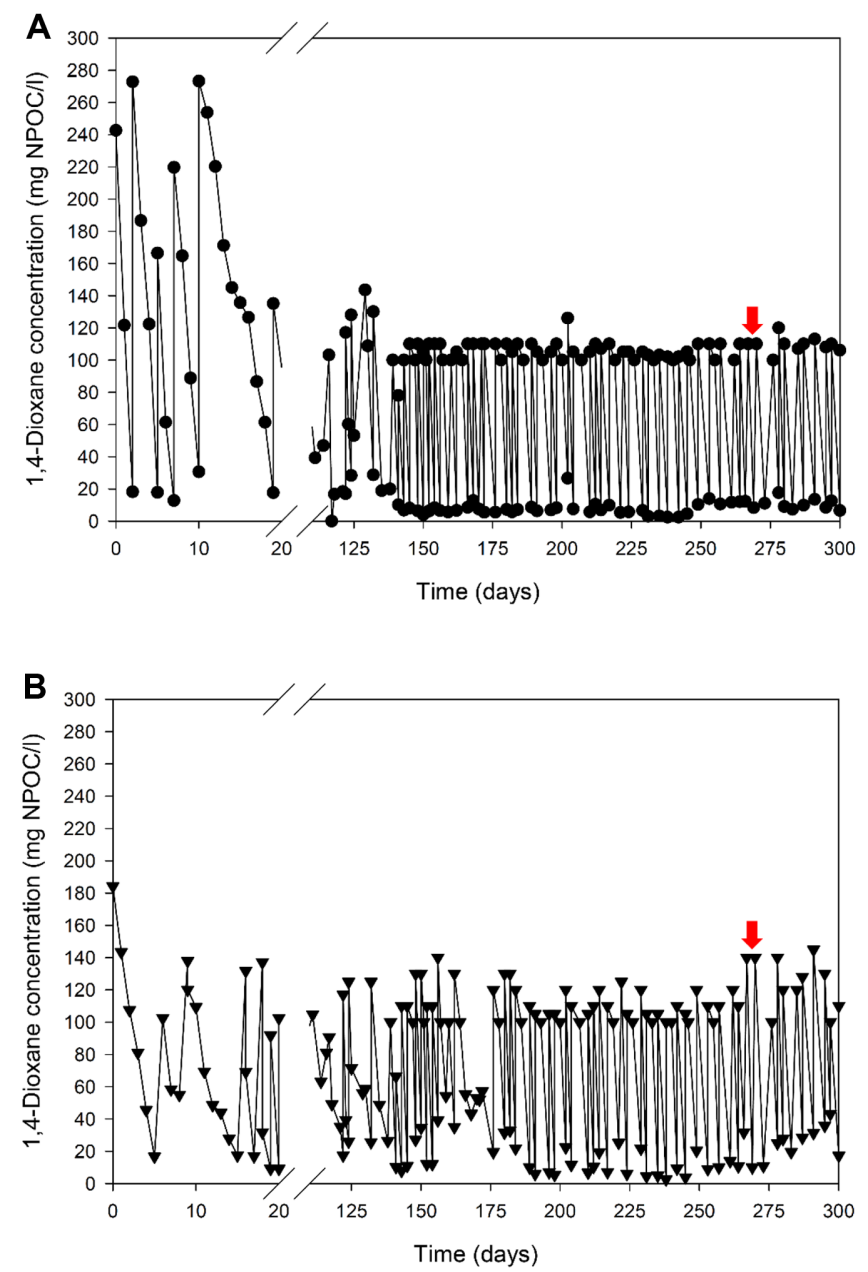

Fig. 1. Long-term enrichment cultivation of forest soil (FS) and activated sludge (AS) for 1,4-dioxane degradation.

(A) Enrichment culture of FS in a shaken flask at $30^{\circ} \mathrm{C}$. (B) Enrichment culture of AS in an aerated $(0.21 / \mathrm{min})$ cylindrical reactor at room temperature $\left(23-25^{\circ} \mathrm{C}\right)$. TSS of a previous culture was centrifuged and resuspended in phosphate-buffered saline three times before adding into the fresh medium for the next round of enrichment. The arrows on 270 days indicate sampling points for the analyses of kinetic parameters and bacterial community, and qPCR.

and the concentration of TSS increased from 430 to $540 \mathrm{mg} / \mathrm{l}$. These batch data were processed to obtain specific growth rates and specific 1,4-dioxane degradation rates for time intervals, and fitted into the Monod and Michaelis-Menten equations.

The determined kinetic parameters of enriched FS, AS, and previously reported 1,4-dioxane degraders are summarized in Table 2. The $\mu_{\max }$ of 1,4-dioxane degraders was reported to be in the range of $0.003-0.10 \mathrm{~h}^{-1}$. The $\mu_{\max }$ of enriched AS on 1,4-dioxane was $0.008 \mathrm{~h}^{-1}$, which was similar to those of industrial activated sludges (0.005- 


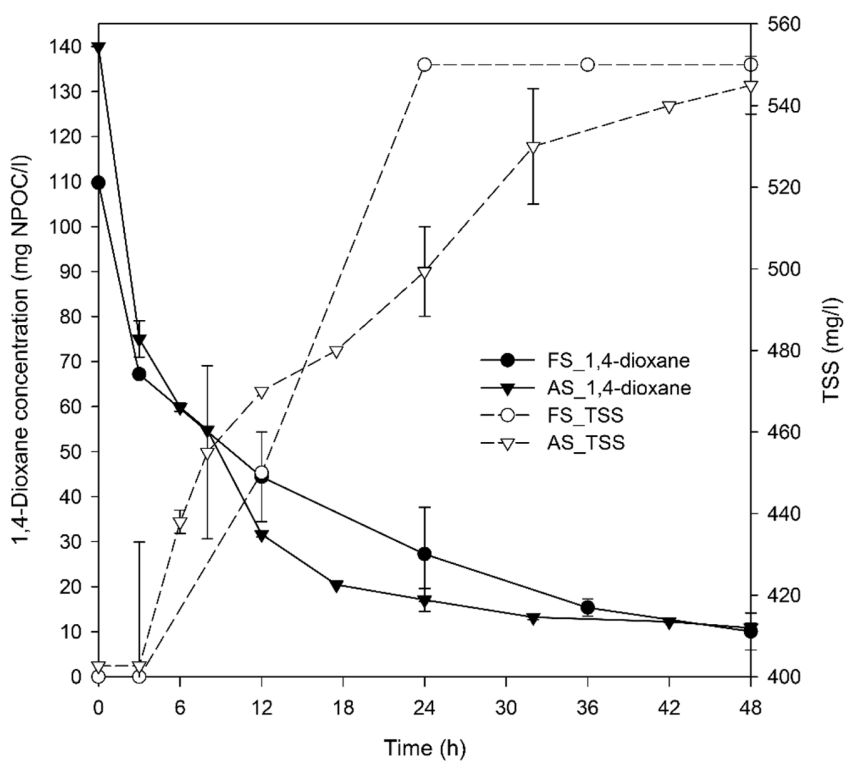

Fig. 2. Time course of 1,4-dioxane and cell growth during enrichment on Days 270-272.

The error bars represent the standard deviation of three replicates.

$\left.0.014 \mathrm{~h}^{-1}\right)$. The cell growth yields of enriched FS and AS were 0.58 and $0.34 \mathrm{mg}$ protein/mg dioxane, respectively. These yields were in the range of previously reported values (0.03-0.50 mg protein/mg dioxane). The $\mathrm{V}_{\max }$ and
$\mathrm{K}_{\mathrm{m}}$ of enriched FS were $0.037 \mathrm{mg}$ dioxane $/ \mathrm{mg}$ protein $\mathrm{h}$ and $93.9 \mathrm{mg} / \mathrm{l}$, respectively. In the case of enriched AS, the $\mathrm{V}_{\max }$ and $\mathrm{K}_{\mathrm{m}}$ values were $0.078 \mathrm{mg}$ dioxane/mg protein $\mathrm{h}$ and $181.3 \mathrm{mg} / \mathrm{l}$, respectively. The $\mathrm{K}_{\mathrm{m}}$ values of FS and AS were in the range of other previously reported 1,4-dioxanedegrading bacteria $(1.65-330 \mathrm{mg} / \mathrm{l})$, and the $\mathrm{K}_{\mathrm{m}}$ value of AS was similar to that of an industrial activated sludge (181.9 mg/l) [39] and P. dioxanivorans CB1190 (160 mg/l) [31]. The $V_{\max }$ value of FS was relatively lower than those of previous studies, probably because the enrichment culture obtained in this study contained non-dioxane degraders. Low $\mathrm{V}_{\max }$ was also reported for Pseudonocardia sp. ENV478 (0.053 mg dioxane/mg protein h) [43], Mycobacterium sp. D11 (0.052 $\mathrm{mg}$ dioxane/mg protein $\cdot \mathrm{h}$ ) [41], and an enrichment culture (0.05 $\mathrm{mg}$ dioxane/mg protein $\cdot \mathrm{h})$ [47].

\section{Bacterial Community Analysis on 16S rRNA Gene Sequences}

In order to identify the bacterial populations contained in enrichment cultures, 16S rRNA genes of enriched FS and AS (collected on Day 270) were PCR-amplified and cloned into E. coli $\mathrm{DH} 5 \alpha$, and 47 (FS) and 101 (AS) clones were analyzed. The obtained sequences of the cloned 16S rRNA gene were deposited in the GenBank/EMBL DNA database under the accession numbers of KT832611-KT832646, KT992721-KT992771, KU000902-KU000912, and KX197123KX197172.

Table 2. Kinetic parameters of 1,4-dioxane biodegradation by different cultures.

\begin{tabular}{|c|c|c|c|c|c|c|}
\hline Culture & $\begin{array}{c}\text { Temp. } \\
\left({ }^{\circ} \mathrm{C}\right)\end{array}$ & $\begin{array}{l}\mu_{\max } \\
\left(\mathrm{h}^{-1}\right)\end{array}$ & $\begin{array}{c}\mathrm{Y} \\
\text { (mg protein/ } \\
\text { mg dioxane) }\end{array}$ & $\begin{array}{c}\mathrm{V}_{\max } \\
\text { (mg dioxane/ } \\
\mathrm{mg} \text { protein } \cdot \mathrm{h} \text { ) }\end{array}$ & $\begin{array}{c}\mathrm{K}_{\mathrm{m}} \\
(\mathrm{mg} / \mathrm{l})\end{array}$ & Reference \\
\hline Pseudonocardia dioxanivorans CB1190 & 30 & 0.10 & 0.09 & $\begin{array}{c}1.1 \pm 0.008 \\
\text { at } 1,000 \mathrm{ppm}\end{array}$ & $160 \pm 44$ & [31] \\
\hline Pseudonocardia benzenivorans B5 & 30 & 0.003 & 0.03 & $\begin{array}{c}0.1 \pm 0.006 \\
\text { at } 1,000 \mathrm{ppm}\end{array}$ & $330 \pm 82$ & [31] \\
\hline Pseudonocardia sp. ENV478 & 30 & - & - & 0.053 at $25 \mathrm{ppm}$ & - & [45] \\
\hline Afipia sp. D1 & 28 & - & 0.19 & 0.263 at $500 \mathrm{ppm}$ & 25.8 & [41] \\
\hline Mycobacterium sp. D6 & 28 & - & 0.19 & 0.139 at $500 \mathrm{ppm}$ & 20.6 & [41] \\
\hline Mycobacterium sp. D11 & 28 & - & 0.18 & 0.052 at $500 \mathrm{ppm}$ & 69.8 & [41] \\
\hline Pseudonocardia sp. D17 & 28 & - & 0.22 & 0.096 at $500 \mathrm{ppm}$ & 59.7 & [41] \\
\hline Industrial activated sludge & - & 0.062 & 0.344 & - & 1.65 & [49] \\
\hline Industrial activated sludge & - & 0.005 & - & - & 181.9 & [39] \\
\hline Industrial activated sludge & $25 \sim 35$ & $0.010 \sim 0.043$ & $0.18 \sim 0.50$ & 0.12 at $100 \mathrm{ppm}, 30^{\circ} \mathrm{C}$ & 9.9 & [12] \\
\hline Enrichment culture & 35 & 0.083 & 0.30 & $\begin{array}{l}0.05 \pm 0.003 \\
\text { at } 200 \mathrm{ppm}\end{array}$ & $12.6 \pm 7.6$ & [48] \\
\hline Enrichment culture-FS & 30 & 0.0004 & 0.58 & 0.037 at $110 \mathrm{ppm}$ & 93.9 & This study \\
\hline Enrichment culture-AS & $22 \sim 25$ & 0.008 & 0.34 & 0.078 at $140 \mathrm{ppm}$ & 181.3 & This study \\
\hline
\end{tabular}

For consistency of dimensions, a protein was assumed to constitute $40 \%$ of TSS, $43 \%$ of COD, and $50 \%$ of VSS [31]. Value converted from mg COD/1 to mg 1,4-dioxane/ 1 based on $1.82 \mathrm{mg} \mathrm{COD/mg} \mathrm{1,4-dioxane} \mathrm{[49].}$ 
Table 3. Bacterial compositions and diversity estimates of the 16S rRNA gene clone library.

\begin{tabular}{|c|c|c|c|c|c|c|}
\hline & Phylum & Class (Order) & Family & Genus & FS & AS \\
\hline \multirow{27}{*}{$\begin{array}{l}\text { Composition } \\
(\%)\end{array}$} & \multirow[t]{3}{*}{ Actinobacteria } & Acidimicrobiia (Acidimicrobiales) & Acidimicrobiaceae & Aciditerrimonas & 2.13 & - \\
\hline & & \multirow[t]{2}{*}{ Actinobacteria (Actinomycetales) } & Mycobacteriaceae & Mycobacterium & 38.30 & 0.99 \\
\hline & & & Nocardiaceae & Rhodococcus & - & 0.99 \\
\hline & Armatimonadetes & Fimbriimonadia (Fimbriimonadales) & Fimbriimonadaceae & Fimbriimonas & - & 3.96 \\
\hline & \multirow[t]{4}{*}{ Bacteroidetes } & Flavobacteria (Flavobacteriales) & Cryomorphaceae & Wandonia & - & 7.92 \\
\hline & & \multirow[t]{3}{*}{ Sphingobacteria (Sphingobacteriales) } & \multirow[t]{3}{*}{ Chitinophagaceae } & Chitinophaga & - & 0.99 \\
\hline & & & & Flavisolibacter & 4.26 & - \\
\hline & & & & Terrimonas & 2.13 & 3.96 \\
\hline & Chloroflexi & Unclassified Chloroflexi bacterium & & & 6.38 & - \\
\hline & \multirow[t]{14}{*}{ Proteobacteria } & \multirow{4}{*}{$\begin{array}{l}\text { Alpha-proteobacteria } \\
\text { (Rhizobiales and Rhodospirillales) }\end{array}$} & \multirow[t]{2}{*}{ Bradyrhizobiaceae } & Afipia & 10.64 & 3.96 \\
\hline & & & & Nitrobacter & - & 0.99 \\
\hline & & & \multirow[t]{2}{*}{ Acetobacteraceae } & Acidisphaera & - & 0.99 \\
\hline & & & & Gluconacetobacter & - & 0.99 \\
\hline & & \multirow{5}{*}{$\begin{array}{l}\text { Beta-proteobacteria } \\
\text { (Burkholderiales) }\end{array}$} & Alcaligenaceae & Paralcaligenes & - & 0.99 \\
\hline & & & Burkholderiaceae & Albidiferax & - & 2.97 \\
\hline & & & & Burkholderia & - & 0.99 \\
\hline & & & & Pandoraea & 8.51 & - \\
\hline & & & Comamonadaceae & Variovorax & - & 0.99 \\
\hline & & \multirow{5}{*}{$\begin{array}{l}\text { Gamma-proteobacteria } \\
\text { (Legionellales and Xanthomonadales) }\end{array}$} & Legionellaceae & Legionella & - & 0.99 \\
\hline & & & Xanthomonadaceae & Dokdonella & 19.15 & 4.95 \\
\hline & & & & Dyella & - & 4.95 \\
\hline & & & & Rhodanobacter & 2.13 & 0.99 \\
\hline & & & & Rudaea & 6.38 & 2.97 \\
\hline & Verrucomicrobia & Unclassified Verrucomicrobia & & & - & 1.98 \\
\hline & \multicolumn{2}{|c|}{ Candidate division TM7 } & & & - & 49.50 \\
\hline & \multicolumn{2}{|c|}{ Candidate division OP10 } & & & - & 0.99 \\
\hline & \multicolumn{2}{|c|}{ Unclassified bacterium } & & & - & 0.99 \\
\hline \multirow[t]{4}{*}{ Diversity } & \multicolumn{2}{|l|}{ Number of clones } & & & 47 & 101 \\
\hline & \multicolumn{2}{|l|}{ Number of OTUs } & & & 10 & 23 \\
\hline & \multicolumn{2}{|c|}{ Shannon-Weaver index of diversity $\left(\mathrm{H}^{\prime}, \mathrm{H}^{\prime}=-\sum \mathrm{P}_{\mathrm{i}} \ln \mathrm{P}_{\mathrm{i}}\right)^{\mathrm{a}}$} & & & 2.69 & 3.05 \\
\hline & \multicolumn{2}{|c|}{ Simpson's index of diversity $\left(\mathrm{D}, \mathrm{D}=\sum \mathrm{P}_{\mathrm{i}}^{2}\right)^{\mathrm{b}}$} & & & 0.21 & 0.26 \\
\hline
\end{tabular}

${ }^{a}$ Shannon-Weaver index; a higher number represents higher diversity; $\mathrm{P}_{\mathrm{i}}$ : proportional abundance of ecosystem $\mathrm{i}$.

'Simpson's index; a higher number represents lower dominance; $P_{i}$ : proportional abundance of ecosystem i.

16S rRNA gene sequences obtained from FS enrichment culture were assigned to four different phyla, including Proteobacteria (46.8\%), Actinobacteria $(40.4 \%)$, Bacteroidetes (6.4\%), and Chloroflexi (6.4\%) (Table 3). At the genus level, clones that belonged to Mycobacterium (38.3\%), Dokdonella $(19.2 \%)$, and Afipia (10.6\%) were identified as members of large clusters. Aerobic 1,4-dioxane-degrading bacteria are usually gram-positive, and most of them belong to the Actinomycetales in the genera Mycobacterium, Pseudonocardia, and Rhodococcus [30, 41]. Afipia strains are known to be aerobic 1,4-dioxane-degrading gram-negative bacteria [41]. Mycobacterium and Afipia (ca. 48.9\%) made up the largest population in enriched FS. The members of genus Mycobacterium were especially predominant in enriched FS, and the 18 clones (1 group) that showed $96-100 \%$ similarity with Mycobacterium were closely related to Mycobacterium sp. PH-06 according to the phylogenetic analysis (Fig. 3). Mycobacterium sp. PH-06 is well known to degrade 1,4dioxane as the sole carbon and energy source [19]. The members of genus Afipia were also dominant in enriched 


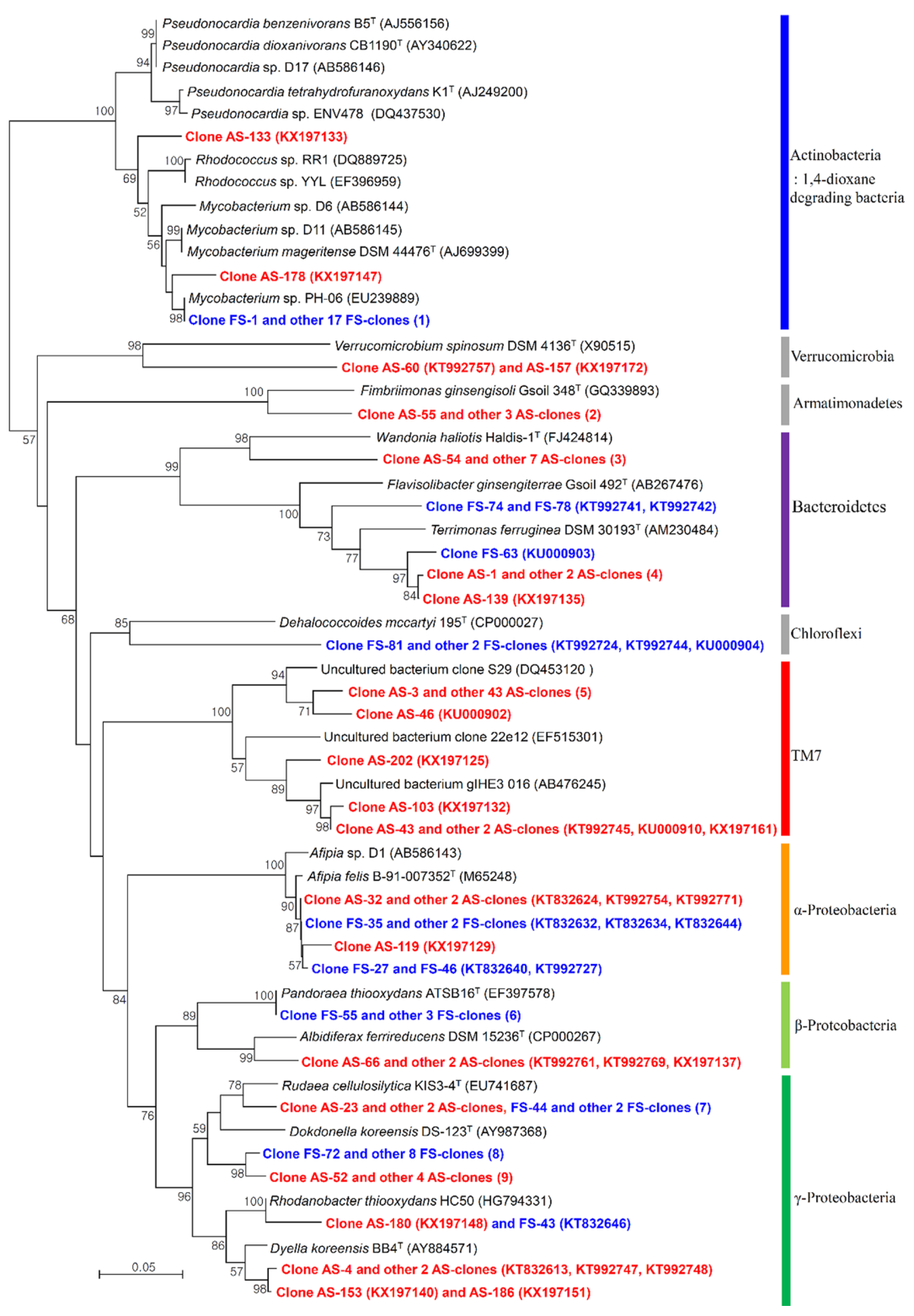

Fig. 3. Phylogenetic tree based on the partial sequences of the $16 \mathrm{~S}$ rRNA gene obtained from enrichment cultures FS and AS. The tree was constructed by using the neighbor-joining method and the sequences of Aquifex pyrophilus (M83548) as an out-group. The bootstrap values above $50 \%$ are shown at the internal nodes. Actinobacteria (1,4-dioxane-degrading bacteria) of clone FS-1 and other 17 FS-clones (1) were of the following accession numbers: KT832628, KT832635, KT832636, KT832638, KT832639, KT832641-KT832643, KT992723, KT992726, KT992728KT992730, KT992732, KT992733, KT992736, KT992737, and KU000911. Armatimonadetes of clone AS-55 and other 3 FS-clones (2) were given accession numbers KT992753, KX197160, KX197170, and KX197171. Bacteroidetes of clone AS-54 and other 7 AS-clones (3) were of KT992752, KT992770, KX197123, KX197127, KX197144, KX197146, KX197153, and KX197163; and AS-1 and other 2 AS-clones (4) were of KT832611, KT832622, and KT992768. TM7 of clone AS-3 and other 43 AS-clones (5) of the following accession numbers were used for construction of the phylogenetic tree: KT832612, KT832614, KT832617, KT832620, KT832621, KT832623, KT832625, KT832627, KT992749, KT992751, KT992755, KT992758-KT992760, KT992762, KT992764-KT992767, KX197124, KX197126, KX197128, KX197131, KX197136, KX197138, KX197139, KX197141KX197143, KX197145, KX197149, KX197150, KX197152, KX197154, KX197155, KX197157, KX197159, KX197162, and KX197164-KX197169. Betaproteobacteria of clone FS-55 and other 3 FS-clones (6) were given the accession numbers KT832630, KT992731, KT992740, and KU000912. Gamma-proteobacteria of clone AS-23 and 2 other AS-clones, FS-44 and 2 other FS-clones (7) were KU000906, KX197134, KX197158, KT992725, KT992734, and KT992743. Clone FS-72 and 8 other FS-clones (8) were used KT832629, KT832631, KT832633, KT832637, KT832645, KT992721, KT992722, KT992735, and KT992739. Clone AS-52 and 4 other AS-clones (9) of the following accession numbers were used for construction of the phylogenetic tree: KT832618, KT992746, KT992750, KT992756, and KX197156. 


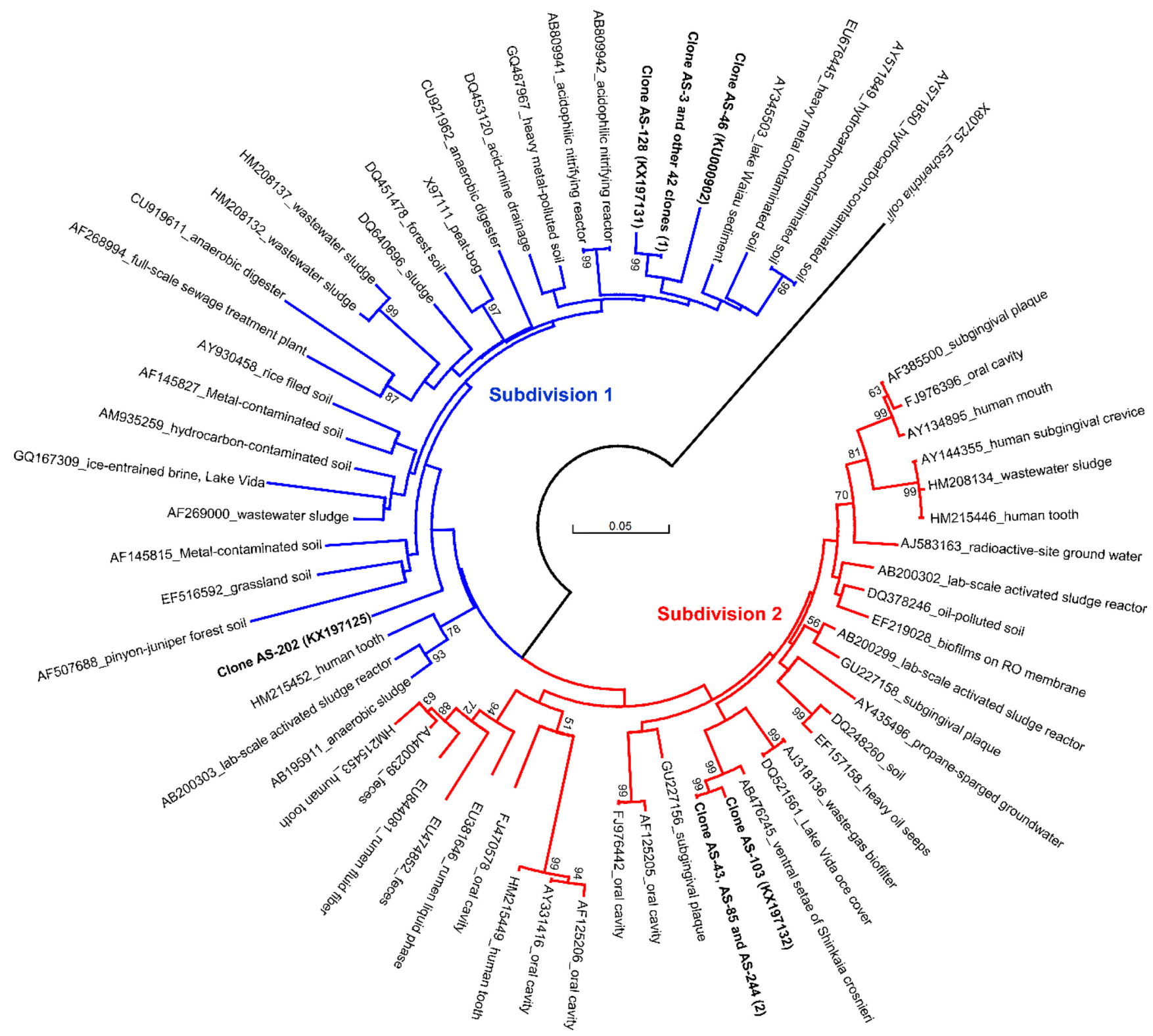

Fig. 4. Phylogenetic tree of TM7-like bacterial clones within candidate division TM7.

The 16S rRNA gene sequences of representative TM7 bacterium clones were retrieved from the GenBank database and incorporated into the tree. TM7-like clones from enriched AS are bold-faced. The Subdivision 1 and 2 are shown with blue and red branches, respectively. Subdivision 1 and 2 are based on the classification systems of Dinis et al. [8], Hanada et al. [16], and Winsley et al. [46], which consist mainly of clones from natural environments and wastewater and humans and animals, respectively. The tree was constructed by using the neighbor-joining method and the sequences of E. coli (X80725) as an out-group. The bootstrap values above $50 \%$ are shown on the internal nodes. TM7 of clone AS-3 and other 42 AS-clones (1) of the following accession numbers were used for construction of the phylogenetic tree: KT832612, KT832614, KT832617, KT832620, KT832621, KT832623, KT832625, KT832627, KT992749, KT992751, KT992755, KT992758-KT992760, KT992762, KT992764-KT992767, KX197124, KX197126, KX197128, KX197136, KX197138, KX197139, KX197141-KX197143, KX197145, KX197149, KX197150, KX197152, KX197154, KX197155, KX197157, KX197159, KX197162, and KX197164-KX197169. Clones AS-72, AS-85, and AS-244 (2) were KT992745, KU000910, and KX197161, respectively.

FS, and the five clones were related to Afipia sp. D1 through phylogenetic analysis. Afipia sp. D1 is also well known to degrade 1,4-dioxane as the sole carbon and energy source
[41]. Many other genera, such as Dokdonella (19.2\%) and Pandoraea (8.5\%), have never been reported to be involved in 1,4-dioxane degradation. However, the bacterial strains 
of genus Dokdonella were reportedly observed in enrichment culture with polycyclic aromatic hydrocarbons [1, 7]. Strains of the genus Pandoraea were also observed in polychlorobiphenyl-contaminated soil [13, 28].

16S rRNA gene sequences identified from AS enrichment culture showed relatively low similarity values (83-99\%) with entries in the GenBank databases, and they were distributed over the phylogenetic tree away from the wellknown 1,4-dioxane-degrading bacteria (Fig. 3). Major phyla in the enriched AS were candidatus Saccharibacteria (formerly candidate division TM7, 49.5\%), Proteobacteria $(27.7 \%)$, and Bacteroidetes (12.9\%) (Table 3). At the genus level, members in enriched AS were more diverse than in enriched FS. The TM7 members were particularly predominant in enriched AS, as they occupied $49.5 \%$ of the clone libraries (Table 3, Fig. 3). Strains in the genera Wandonia (7.9\%), Dokdonella (5.0\%), and Dyella (5.0\%) were also found. Table 3 also shows the diversity estimates of both libraries obtained by the Shannon-Weaver and Simpson's indices. The diversities of enriched AS were a little higher than those of enriched FS.

Within the candidate phylum TM7, Dinis et al. [8] reported that Subdivision 1 consisted almost exclusively of OTUs obtained from natural and wastewater samples (environmental associated), whereas Subdivision 2 was mostly OTUs of human and animal sources (host associated). However, some clones from wastewater, soil, and contaminated sites were classified into the host-associated clade $[16,46]$. In accordance with this classification, the 50 clones (3 groups) that showed low similarity (83-99\%) with TM7 bacteria were closely related to Subdivision 1 (Fig. 4). This result indicated that the TM7-like bacterial group in enriched AS was important for 1,4-dioxane degradation in unknown ways.

\section{Copy Numbers of 16S rRNA and SDIMO Genes}

SDIMOs were reportedly involved in metabolic and cometabolic 1,4-dioxane degradation [11, 31]. SDIMOs are key multicomponent enzymes catalyzing the initial oxidation stage of hydrocarbons in phylogenetically and physiologically diverse bacteria; these enzymes could be categorized into five groups according to substrate specificity, sequence similarity, and component arrangement [5, 25]. Among them, Group 5 SDIMOs (THF/dioxane and propane monooxygenases) play an essential role in the initial oxidation stage of the cyclic ethers THF and 1,4-dioxane. Hence, it would be of interest to predict the dioxane degradation potential by assessing the SDIMO gene as a biomarker. The $16 \mathrm{~S}$ rRNA and SDIMO gene copy numbers

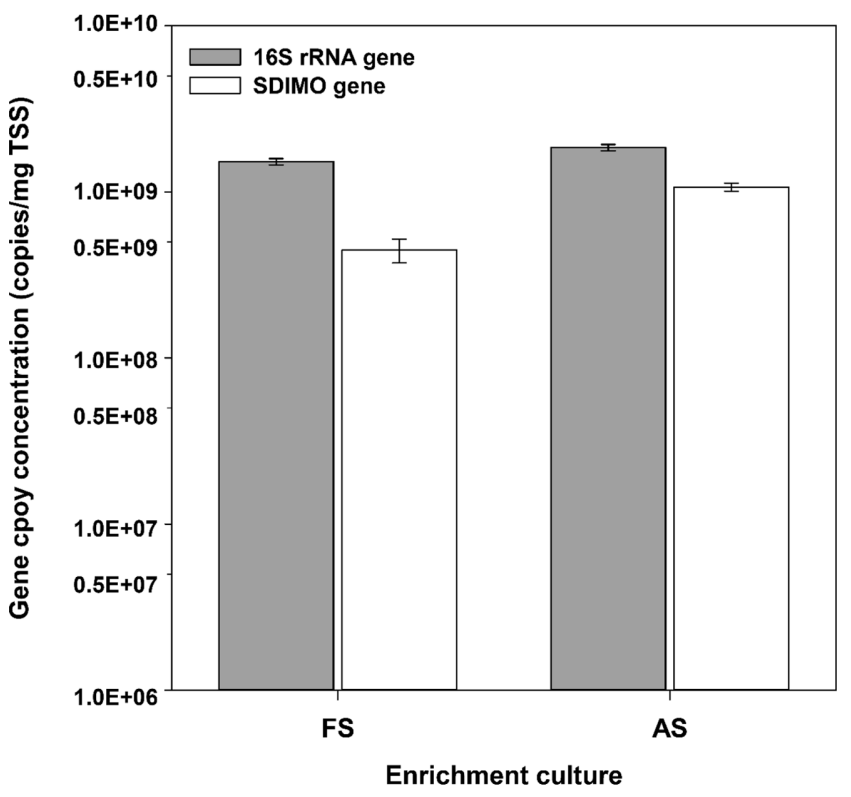

Fig. 5. Quantification of the eubacterial $16 \mathrm{~S}$ rRNA and soluble di-iron monooxygenase (SDIMO) genes in enriched FS and AS.

The values of gene copies were the average of quintuplicate experiments. Error bars represent the standard deviation.

per $1 \mathrm{mg}$ TSS are shown in Fig. 5. The abundance of $16 \mathrm{~S}$ rRNA and SDIMO genes in the enriched FS sampled at Day 270 were $1.52( \pm 0.07) \times 10^{9}$ copies $/ \mathrm{mg}$ TSS and $0.45( \pm 0.07)$ $\times 10^{9}$ copies/mg TSS, respectively. For enriched AS, 16S rRNA and SDIMO gene copy numbers were $1.85( \pm 0.08) \times$ $10^{9}$ copies/mg TSS and $1.07( \pm 0.06) \times 10^{9}$ copies $/ \mathrm{mg}$ TSS, respectively. The average abundance relative to total bacteria (average SDIMO/16S rRNA gene copies) in enriched FS and AS were $29.4 \%$ and $57.8 \%$, respectively. These results suggested that quantitative measurement of the SDIMO gene might be useful for monitoring 1,4-dioxane-degrading bacteria and probably other closely related pollutantdegrading bacteria.

In order to further verify that the amplicons obtained from enrichment cultures were fragments of the targeted SDIMO genes, 31 clone libraries were constructed with genomic DNA extracted from enriched FS and AS (collected on Day 270) by sequencing and alignment. Through SDIMO gene library construction and sequencing, it was confirmed that OTUs of enriched AS and FS contained the QSDE(S/A)RHI motif and belonged to Group 5 SDIMOs (data not shown). Phylogenetic analyses allocated all SDIMO clones of both enrichment cultures to the Group 5 SDIMOs with 97-98\% similarity to Rhodococcus sp. YYL, P. 


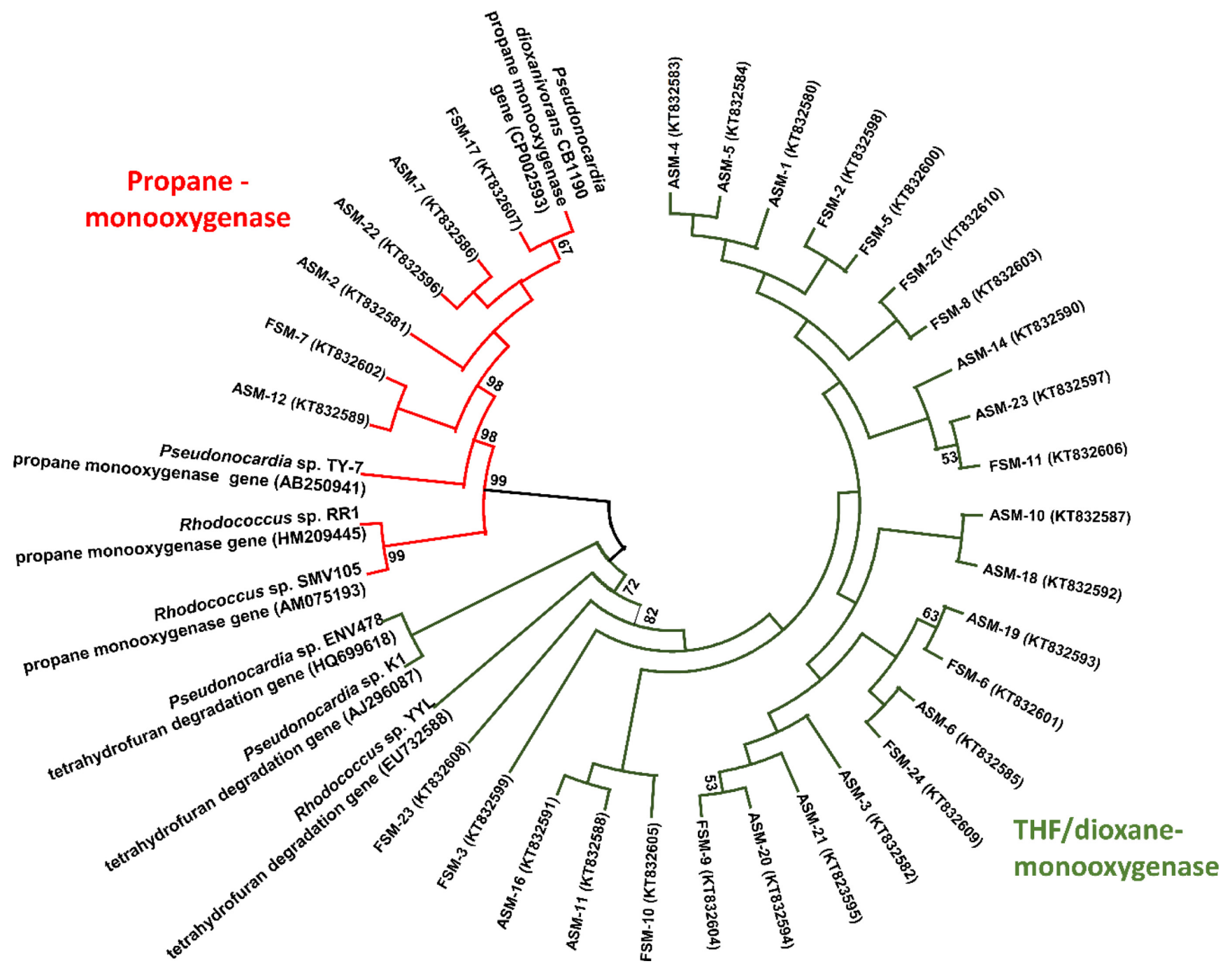

Fig. 6. Phylogenetic tree of the partial sequences of soluble di-iron monooxygenase genes cloned from enrichment cultures FS and AS.

The tree was constructed by using the neighbor-joining method, and bootstrap values above $50 \%$ are shown on the internal nodes.

dioxanivorans CB1190, and Pseudonocardia sp. TY-7 (Fig. 6). In particular, the THF/dioxane monooxygenase of Rhodococcus sp. YYL was predominant, as it occupied $84.6 \%$ in FS and $77.8 \%$ in AS. Other clones were clustered into one group; specifically, the propane monooxygenase ( $\mathrm{prm}$ ) gene of P. dioxanivorans CB1190 or Pseudonorcardia sp. TY-7. $\mathrm{THF} /$ dioxane monooxygenase is known to play a crucial role in dioxane biodegradation [26]. THF monooxygenase (thm) genes of Rhodococcus sp. YYL, Pseudonocardia sp. K1, and Pseudonorcardia sp. ENV478 were highly homologous to the putative dioxane monooxygenase gene $(d x m)$ cluster, based on estimates on the nucleotide sequence identity of each gene (above 97\%) as well as generic component arrangement [26]. Although propane monooxygenases bear a close evolutionary relationship with THF/dioxane monooxygenases and are in the same subdivision (Group 5), they do not share the same substrate range. However, our studies with enrichment cultures suggested that the presence of genes associated with $\mathrm{THF} /$ dioxane monooxygenase and propane monooxygenase are promising indicators of 1,4-dioxane degradation, since enrichment cultures in this study were obtained using 1,4-dioxane as the sole carbon and energy source. As in our study, co-metabolism of 1,4dioxane with bacteria expressing propane monooxygenases was observed in another study [26]. Gedalanga et al. [11] also reported that the prm gene was increasingly expressed in $P$. dioxanivorans CB1190 when over $50 \%$ of the 1,4 dioxane had been removed. Moreover, successful removal 
of dioxane in microcosms inoculated with propanotrophs was achieved when the initial concentration of dioxane was as high as $10 \mathrm{mg} / 1$ [10]. Therefore, biodegradation of 1,4dioxane might be correlated with the prm gene, as found in the enrichment culture of FS and AS. Sequences of the cloned Group 5 SDIMO gene were deposited in the GenBank/EMBL DNA database under the accession numbers KT832580-KT832610.

\section{Discussion}

Laplante et al. [24] suggested that two independent bacterial communities encountering similar environmental perturbations (e.g., heavy metals and acidic $\mathrm{pH}$ ) exhibited the same overall taxonomical membership (i.e., members in both communities belong to the same high taxonomic rank). Concretely, they argued that community differentiation at the taxonomic diversity level reflected the presence and absence of a perturbation, whereas the community structure level accurately reflected the intensity of the perturbation. In the present study, microorganisms contained in FS and AS were enriched for 300 days using 1,4-dioxane as the sole source of carbon. Long-term exposure to an intense environmental perturbation (1,4-dioxane as a single substrate) significantly changed the microbial community and reduced biodiversity, and the activation of 1,4-dioxane degradation became evident regardless of microbial sources and cultivation conditions (Figs. 1 and 3, Table 3). However, bacterial communities of enriched FS and AS exhibited substantial differences (Fig. 2, Table 3). In enriched FS, previously reported 1,4-dioxane-degrading bacteria were so abundant that Mycobacterium spp. and Afipia spp. occupied approximately half of the enrichment FS. On the contrary, 1,4-dioxane-degrading bacteria were detected as minor populations among the 16S rRNA gene libraries constructed from enriched AS (5.94\%). Surprisingly, the TM7-like bacteria were predominant, as they occupied $49.5 \%$ of the total clones of enriched AS.

Grady et al. [12] reported that the growth of a 1,4-dioxane degrader was highly sensitive to cultivation temperature (environmental stress). Previous studies discovered that the optimum temperature range for microbial degradation of 1,4-dioxane by Actinomycetales (genera Mycobacterium, Pseudonocardia, and Rhodococcus) was $28-35^{\circ} \mathrm{C}[2,3,19,21$, $30,31,35,41,45]$. At a low temperature (below $20^{\circ} \mathrm{C}$ ), 1,4dioxane degraders showed slow growth and removal rates $[12,33,48,51]$. Conversely, Zenker et al. [50] reported that a high temperature $\left(35^{\circ} \mathrm{C}\right)$ was suboptimal for 1,4-dioxane biodegradation. Environmental TM7 bacteria were found mostly at ambient temperatures $\left(16-25^{\circ} \mathrm{C}\right)[6,16,29,47]$. Therefore, it was thought that the 1,4-dioxane-degrading bacteria that belonged to Actinomycetales were absent in enriched AS because the enrichment culture of AS was carried out at room temperature $\left(22-25^{\circ} \mathrm{C}\right)$. According to Bergey's Manual of Systematic Bacteriology [14, 22], Afipia, Dokdonella, and Terrimonas grow well at $25-30^{\circ} \mathrm{C}$; thus, these bacteria could commonly be enriched in FS and AS. It was concluded that the differences in the bacterial community were created by the different cultivation temperature, even though the main selective pressure of enrichment cultivation was identical (1,4-dioxane as the sole carbon source). Moreover, it was suspected that the presence of 1,4dioxane and low temperature might stimulate growth of TM7-like bacteria.

Similarly to bacterial composition, enriched FS and AS showed differences in 1,4-dioxane degradation kinetics. The $\mathrm{K}_{\mathrm{m}}$ value of the enriched FS was confirmed at an intermediate level in previously reported $\mathrm{K}_{\mathrm{m}}$ values for 1,4dioxane degradation, and was similar to that of Mycobacterium sp. D11 (Table 2). On the other hand, the $\mathrm{K}_{\mathrm{m}}$ of enriched AS was much higher than that of others, which could be advantageous for degrading high concentrations of 1,4-dioxane. Previous studies also emphasized that 1,4dioxane-degrading bacteria with high $\mathrm{K}_{\mathrm{m}}$ could play a significant role in a 1,4-dioxane treatment of above $1 \mathrm{~g} / \mathrm{l}$ $[31,41]$.

Interestingly, it was previously reported that 1,4-dioxanedegrading bacteria were not found in the 16S rRNA gene library of enriched AS, and its 1,4-dioxane degradation kinetic parameters were different from those of enriched FS. Another unique feature of enriched AS was that TM7like bacteria were the most dominant group in the clones (Table 3). This finding suggested that TM7-like bacteria might degrade 1,4-dioxane by directly using it as a carbon and energy source or by metabolizing the by-products from 1,4-dioxane oxidation reaction in other microorganisms. The phylum candidate division TM7 has been observed with two monophyletic subdivisions at class-level clades [8]. Subdivision 1 is characterized by phylotypes mostly from environmental sources (soil, rhizosphere, marine, freshwater, wastewater, and contaminated sites), whereas Subdivision 2 includes phylotypes from animals, humans, and some environmental sources. TM7-like bacteria are of particular interest because they have been found in a variety of habitats; a stable culture of any species in this phylum has never been made, and habitats in which TM7 bacteria constitute the major population have so far not been reported $[8,17,29,46]$. The relative abundance of this 
phylum within the samples ranged from $0.05 \%$ to $3.02 \%$ of the microbial community $[8,16,46]$. Our results showed that TM7-like bacteria occupied $49.5 \%$ of the clone libraries constructed from enriched AS, and most of the OTUs belonged to Subdivision 1 (environmental-associated clade). Furthermore, enriched AS actively removed 1,4dioxane. Similar results were reported by Hanada et al. [16], who showed that members of the candidate phylum TM7 of the 16S rRNA gene clone library were prevalent $(33 \%)$ in fully acclimated acidophilic nitrifying sequencingbatch reactors, but they could not clearly explain why TM7 bacteria were abundant. Connon et al. [6] reported that TM7 bacteria (385 bp of LH-PCR fragment) were predominant (31.5\% of the total fragments) in the TCE-contaminated groundwater treatment process using propane sparging, TCE, and cis-DCE (dichloroethene); propane removal rates were correlated with the increase in the $385 \mathrm{bp}$ fragment proportion. Luo et al. [29] and Xie et al. [47] also reported on the candidate phylum TM7, where the dominant bacterium responsible for carbon uptake from toluene (11.3-62.1\% of total T-RFLP fragments) and benzene (84.1\% of the total T-RFLP fragments) in agricultural soil was identified by DNA stable isotope probing. In addition, a putative dihydroxybiphenyl dioxygenase (GenBank Acc. No. AKM80657) gene was suggested in TM7 metagenomic sequences (GenBank Acc. No. CP011211). However, genes encoding the degradation of toluene, benzene, and 1,4dioxane have not been reported in TM7 bacteria. Although the ecophysiological significance and enzyme systems of the TM7-like bacteria remain unclear, these results suggested that candidate phylum TM7 might play an important role in 1,4-dioxane degradation. To our best knowledge, this is the first report on TM7 bacteria utilizing 1,4-dioxane as the sole carbon and energy source during biodegradation. Therefore, further studies are necessary to isolate microorganisms in TM7 and related taxa and to reveal the metagenomic characteristics of axenic cultures.

\section{Acknowledgments}

This subject was supported by the Korea Ministry of Environment (MOE) as "Advanced Technology Program for Environmental Industry" under Contract No. 2013001340002.

\section{References}

1. Alonso-Gutiérrez J, Figueras A, Albaigés J, Jiménez N, Viñas M, Solanas AM, Novoa B. 2009. Bacterial communities from shoreline environments (Costa da Morte, Northwestern Spain) affected by the Prestige oil spill. Appl. Environ. Microbiol. 75: 3407-3418.

2. Bernhardt D, Diekmann H. 1991. Degradation of dioxane, tetrahydrofuran and other cyclic ethers by an environmental Rhodococcus strain. Appl. Microbiol. Biotechnol. 36: 120-123.

3. Burback BL, Perry JJ. 1993. Biodegradation and biotransformation of groundwater pollutant mixtures by Mycobacterium vaccae. Appl. Environ. Microbiol. 59: 1025-1029.

4. Coleman HM, Vimonses V, Leslie G, Amal R. 2007. Degradation of 1,4-dioxane in water using $\mathrm{TiO}_{2}$ based photocatalytic and $\mathrm{H}_{2} \mathrm{O}_{2} / \mathrm{UV}$ processes. J. Hazard. Mater. 146: 496-501.

5. Coleman NV, Bui NB, Holmes AJ. 2006. Soluble di-iron monooxygenase gene diversity in soils, sediments and ethene enrichments. Environ. Microbiol. 8: 1228-1239.

6. Connon SA, Tovanabootr A, Dolan M, Vergin K, Giovannoni SJ, Semprini L. 2005. Bacterial community composition determined by culture-independent and -dependent methods during propane-stimulated bioremediation in trichloroethenecontaminated groundwater. Environ. Microbiol. 7: 165-178.

7. Ding GC, Heuer H, Smalla K. 2012. Dynamics of bacterial communities in two unpolluted soils after spiking with phenanthrene: soil type specific and common responders. Front. Microbiol. 3: Article 290.

8. Dinis JM, Barton DE, Ghadiri J, Surendar D, Reddy K, Velasquez F, et al. 2011. In search of an uncultured humanassociated TM7 bacterium in the environment. PLoS One 6: e21280.

9. Felsenstein J. 1985. Confidence limits on phylogenies: an approach using the bootstrap. Evolution 39: 783-791.

10. Findlay M, Smoler D, Fogel S. 2007. Dioxane-degrading propanotrophs for in-situ remediation. In: Battelle Conference: In Situ and On-Site Bioremediation Symposium, Baltimore, Maryland, USA.

11. Gedalanga PB, Pornwongthong P, Mora R, Chiang SY, Baldwin B, Ogles D, Mahendra S. 2014. Identification of biomarker genes to predict biodegradation of 1,4-dioxane. Appl. Environ. Microbiol. 80: 3209-3218.

12. Grady CPL, Sock SM, Cowan RM. 1997. Biotreatability kinetics. Biotechnology in the Sustainable Environment. In Sayler GS, Sanseverino J, Davis KL (eds.). Plenum Press, New York, USA.

13. Gómez-Gil L, Kumar P, Barriault D, Bolin JT, Sylvestre M, Eltis LD. 2007. Characterization of biphenyl dioxygenase of Pandoraea pnomenusa B-356 as a potent polychlorinated biphenyl-degrading enzyme. J. Bacteriol. 189: 5705-5715.

14. Garrity GM, Brenner DJ, Krieg NR, Staley JT. 2005. Bergey's Manual of Systematic Bacteriology; Volume Two: The Proteobacteria; Part C: The Alpha-, Beta-, Delta-, and Epsilonproteobacteria. Springer, New York, USA.

15. Han JS, So MH, Kim CG. 2009. Optimization of biological 
wastewater treatment conditions for 1,4-dioxane decomposition in polyester manufacturing processes. Water Sci. Technol. 59: 995-1002.

16. Hanada A, Kurogi T, Giang NM, Yamada T, Kamimoto Y, Kiso Y, Hiraishi A. 2014. Bacteria of the candidate phylum TM7 are prevalent in acidophilic nitrifying sequencing-batch reactors. Microbes Environ. 29: 353-362.

17. Hugenholtz P, Tyson GW, Webb RI, Wagner AM, Blackall LL. 2001. Investigation of candidate division TM7, a recently recognized major lineage of the domain bacteria with no known pure-culture representatives. Appl. Environ. Microbiol. 67: 411-419.

18. Kampfer P, Kohlweyer U, Thiemer B, Andreesen JR. 2006. Pseudonocardia tetrahydrofuranoxydans sp. nov. Int. J. Syst. Evol. Microbiol. 56: 1535-1538.

19. Kim YM, Jeon JR, Murugesan K, Kim EJ, Chang YS. 2009. Biodegradation of 1,4-dioxane and transformation of related cyclic compounds by a newly isolated Mycobacterium sp. PH-06. Biodegradation 20: 511-519.

20. Kimura M. 1980. A simple method for estimating evolutionary rate of base substitutions through comparative studies of nucleotide sequences. J. Mol. Evol. 16: 111-120.

21. Kohlweyer U, Thiemer B, Schrader T, Andreesen JR. 2000. Tetrahydrofuran degradation by a newly isolated culture of Pseudonocardia sp. strain K1. FEMS Microbiol. Lett. 186: 301-306.

22. Krieg NR, Parte A, Ludwig W, Whitman WB, Hedlund BP, Paster BJ, et al. 2011. Bergey's Manual of Systematic Bacteriology: Volume 4: The Bacteroidetes, Spirochaetes, Tenericutes (Mollicutes), Acidobacteria, Fibrobacteres, Fusobacteria, Dictyoglomi, Gemmatimonadetes, Lentisphaerae, Verrucomicrobia, Chlamydiae, and Planctomycetes. Springer Science \& Business Media.

23. Lane DJ. 1991. 16S/23S rRNA sequencing, pp. 115-175. In Stackebrandt E, Goodfellow M (eds.). Nucleic Acid Techniques In Bacterial Systematics. John Wiley and Sons, Chichester, UK.

24. Laplante K, Sébastien B, Derome N. 2013. Parallel changes of taxonomic interaction networks in lacustrine bacterial communities induced by a polymetallic perturbation. Evol. Appl. 6: 643-659.

25. Leahy JG, Batchelor PJ, Morcomb SM. 2003. Evolution of the soluble diiron monooxygenases. FEMS Microbiol. Rev. 27: 449-479.

26. Li M, Mathieu J, Yang Y, Fiorenza S, Deng Y, He Z, et al. 2013. Widespread distribution of soluble di-iron monooxygenase (SDIMO) genes in Arctic groundwater impacted by 1,4dioxane. Environ. Sci. Technol. 47: 9950-9958.

27. Lippincott D, Streger SH, Schaefer CE, Hinkle J, Stormo J, Steffan RJ. 2015. Bioaugmentation and propane biosparging for In Situ Biodegradation Of 1,4-dioxane. Ground Water Monit. Remediat. 35: 81-92.

28. Liz JAZE, Jan-Roblero J, de la Serna JZD, de León AVP, Hernández-Rodríguez C. 2009. Degradation of polychlorinated biphenyl (PCB) by a consortium obtained from a contaminated soil composed of Brevibacterium, Pandoraea and Ochrobactrum. World J. Microbiol. Biotechnol. 25: 165-170.

29. Luo C, Xie S, Sun W, Li X, Cupples AM. 2009. Identification of a novel toluene-degrading bacterium from the candidate phylum TM7, as determined by DNA stable isotope probing. Appl. Environ. Microbiol. 75: 4644-4647.

30. Mahendra S, Alvarez-Cohen L. 2005. Pseudonocardia dioxanivorans sp nov., a novel actinomycete that grows on 1,4-dioxane. Int. J. Syst. Evol. Microbiol. 55: 593-598.

31. Mahendra S, Alvarez-Cohen L. 2006. Kinetics of 1,4-dioxane biodegradation by monooxygenase-expressing bacteria. Environ. Sci. Technol. 40: 5435-5442.

32. Mohr TKG. 2001. Solvent Stabilizers. Santa Clara Valley Water District, San Jose, California, USA.

33. Mohr TKG, Stickney JA, DiGuiseppi WH. 2010. Environmental Investigation and Remediation: 1,4-Dioxane and Other Solvent Stabilizers. CRC Press, Boca Raton, Florida, USA.

34. Muyzer G, De Waal EC, Uitterlinden AG. 1993. Profiling of complex microbial populations by denaturing gradient gel electrophoresis analysis of polymerase chain reaction-amplified genes coding for 16S rRNA. Appl. Environ. Microbiol. 59: 695-700.

35. Nakamiya K, Hashimoto S, Ito H, Edmonds JS, Morita M. 2005. Degradation of 1,4-dioxane and cyclic ethers by an isolated fungus. Appl. Environ. Microbiol. 71: 1254-1258.

36. Nei M, Kumar S. 2000. Molecular Evolution and Phylogenetics. Oxford University Press, New York, USA.

37. Parales RE, Adamus JE, White N, May HD. 1994. Degradation of 1,4-dioxane by an actinomycete in pure culture. Appl. Environ. Microbiol. 60: 4527-4530.

38. Popoola AV. 1992. Mechanism of reaction involving the formation of dioxane byproduct during the production of poly(ethylene terephthalate). J. Appl. Polym. Sci. 43: 1875-1877.

39. Roy D, Anagnostu G, Chaphalkar P. 1994. Biodegradation of dioxane and diglyme in industrial waste. J. Environ. Sci. Health A Environ. Sci. Eng. 29: 129-147.

40. Sei K, Kakinoki T, Inoue D, Soda S, Fujita M, Ike M. 2010. Evaluation of the biodegradation potential of 1,4-dioxane in river, soil and activated sludge samples. Biodegradation 21: 585-591.

41. Sei K, Miyagaki K, Kakinoki T, Fukugasako K, Inoue D, Ike M. 2013. Isolation and characterization of bacterial strains that have high ability to degrade 1,4-dioxane as a sole carbon and energy source. Biodegradation 24: 665-674.

42. So MH, Han JS, Han TH, Seo JW, Kim CG. 2009. Decomposition of 1,4-dioxane by photo-Fenton oxidation coupled with activated sludge in a polyester manufacturing process. Water Sci. Technol. 59: 1003-1009.

43. Tamura K, Stecher G, Peterson D, Filipski A, Kumar S. 2013. MEGA6: molecular evolutionary genetics analysis version 6.0. Mol. Biol. Evol. 30: 2725-2729.

44. Thompson JD, Higgins DG, Gibson TJ. 1994. CLUSTAL W: improving the sensitivity of progressive multiple sequence alignment through sequence weighting, position-specific 
gap penalties and weight matrix choice. Nucleic Acids Res. 22: 4673-4680.

45. Vainberg S, McClay K, Masuda H, Root D, Condee C, Zylstra GJ, Steffan RJ. 2006. Biodegradation of ether pollutants by Pseudonocardia sp. strain ENV478. Appl. Environ. Microbiol. 72: 5218-5224.

46. Winsley TJ, Snape I, McKinlay J, Stark J, van Dorst JM, Ji M, et al. 2014. The ecological controls on the prevalence of candidate division TM7 in polar regions. Front. Microbiol. 5: Article 345.

47. Xie S, Sun W, Luo C, Cupples AM. 2011. Novel aerobic benzene degrading microorganisms identified in three soils by stable isotope probing. Biodegradation 22: 71-81.

48. Zenker MJ, Borden RC, Barlaz MA. 2000. Mineralization of 1,4-dioxane in the presence of a structural analog. Biodegradation 11: 239-246.

49. Zenker MJ, Borden RC, Barlaz MA. 2002. Modeling cometabolism of cyclic ethers. Environ. Eng. Sci. 19: 215-228.

50. Zenker MJ, Borden RC, Barlaz MA. 2003. Occurrence and treatment of 1,4-dioxane in aqueous environments. Environ. Eng. Sci. 20: 423-432.

51. Zenker MJ, Borden RC, Barlaz MA. 2004. Biodegradation of 1,4-dioxane using trickling filter. J. Environ. Eng. 130: 926-931. 